\title{
PENGARUH VOLUME PERDAGANGAN \\ TERHADAP VOLATILITAS \\ (Studi pada Bursa Efek Indonesia dan New York Stock Exchange)
}

\author{
Ni Putu Ayu Supriati ${ }^{1}$ \\ Ni Luh Putu Wiagustini ${ }^{2}$ \\ ${ }^{1,2}$ Fakultas Ekonomi dan Bisnis Universitas Udayana (Unud), Bali, Indonesia \\ email: ayusupriati30@gmail.com
}

\begin{abstract}
ABSTRAK
Studi ini dilakukan untukmemahami efek volume perdagangan saham pada volatilitas dan mengetahui perbedaan dari hasil pengujian didua pasar yang berbeda. Penelitian ini dilakukan di Bursa Efek Indonesia sertaNew York Stock Exchange dengan memilih IHSG di masing-masing pasar sebagai sampel pada tahun 2013 sampai 2018. Regresi linier dan uji beda dua rata-rata digunakan sebagai teknik utama dalam menganalisis data. Penelitian ini membuktikan bahwa volume perdagangan saham berpengaruh positif siginifikan terhadap volatilitas saham dan pelaku pasar dapat mengambil keputusan dengan berpedoman pada volatilitas saham. Adanya pengaruh tersebut membuktikan peningkatan volume perdagangan menyebabkan semakin tinggi volatilitas. Pengujian yang dilakukan di dua pasar ini mengonfirmasi adanya tingkat volatilitas di kedua pasar, namun volatilitas di Bursa Efek Indonesia lebih tinggi dibandingkan volatilitas New York Stock Exchange. Hasil penelitian juga mengonfirmasi adanya perbedaan pada persentase pengaruh volume perdagangan terhadap volatilitas pada kedua pasar.
\end{abstract}

Kata Kunci: volume perdagangan, volatilitas, bursa efek indonesia, new york stock exhange

\begin{abstract}
The aims of this study is to determine the effect of stock trading volume on volatility, and to find out the differences of test results in two different markets. This research was conducted in the Indonesia Stock Exchange and in the New York Stock Exchange by selecting the Composite Stock Price Index (CSPI), which in each market as a sample in 2013 until 2018. The analysis technique used in this study, namely linear regression and different test two means. The results of this study indicate that stock trading volume has a significant positive effect on stock volatility, and market participants can take decisions based on stock volatility. The effect of the trading volume on volatility indicates that the higher the volume of stock trading will take the higher of the volatility. The test which was conducted in the two markets, confirm that the volatility in both markets, in addition, volatility on the Indonesia Stock Exchange is higher than the volatility of the New York Stock Exchange. The results of this study also confirm about the differences in the percentage of the effect of trading volume on volatility in both markets.
\end{abstract}

Keywords: trading volume, volatility, indonesia stock exchange, new york stock exchange 


\section{PENDAHULUAN}

Investasi merupakan suatu istilah yang tidak asing bagi para ekonom, namun dewasa ini investasi menjadi hal yang sangat menarik dan mulai diminati oleh banyak orang, baik para ekonom itu sendiri, pelajar, bahkan masyarakat pada umumnya yang tidak mempelajari ilmu ekonomi sekali pun. Masyarakat yang memiliki kelebihan dana dan biasanya menghimpun dana tersebut dalam bentuk tabungan, kini mayoritas lebih memilih kegiatan investasi.Pada era digitalisasi seperti saat ini, kegiatan investasi tidak langsung berupa investasi saham semakin diminati oleh masyarakat.Para investor dalam melakukan investasi saham akan memerhatikan dua hal utama, yakni return (keuntungan/pengembalian) dan risiko.Volatilitas menjadi penting karena para investor mulai mengamati perubahan dalam perilaku pasar. Volatilitas merupakan ceminan dari fluktuasi pergerakan harga pada sekuritas berbentuk saham (Tim Studi Volatilitas, 2011). Semakin tinggi volatilitas, maka semakin tinggi ketidakpastian harga saham, hal ini mencerminkan semakin tinggi pula risikonya dengan harapan return yang diraih juga lebih tinggi.Volatilitas ini tidak hanya terjadi di pasar Indonesia, Eaves dan Valero (2009) mengonfirmasi adanya volatilitas di pasar saham Tokyo.

Volatilitas dapat diramalkan dengan adanya informasi atau signal di pasar saham. Informasi tersebut dapat menjadi pendorong bagi investor dalam melakukan kegiatan menjual atau membeli saham, sehingga bagi investor yang pandai dalam memahami informasi akan mudah dalam memprediksi pergerakan pasar. Informasi yang didapat baik dari dalam maupun luar pasar modal merupakan hal yang penting dalam untuk dipertimbangkan oleh investor dalam 
Ni Putu Ayu Supriati, Pengaruh Volume Perdagangan...

mengambil keputusan investasi(Napitulu dan Syahyunan, 2012). Informasi yang dikatakan sebagai motivasi perdagangan ini salah satunya dapat dilihat dari volume perdagangan di pasar tersebut. Volume perdagangan menjadi fokus dalam penelitian ini karena volume perdagangan merupakan cerminan dari kegiatan penawaran dan permintaan di pasar yang erat kaitannya dengan perubahan harga pasar (Tandelilin, 2017:399). Volume perdagangan ini dipengaruhi oleh beberapa faktor, yaitu indeks harga saham, nilai tukar, right issue, dan tingkat suku bunga (Otok dkk., 2006).

Terjadi ketidakstabilan return ekuitas yang disebabkan oleh volume perdagangan, dengan demikian volume perdagangan dapat menjadi salah satu faktor penting dalam menjelaskan volatilitas (Naik et al.,2018). Penelitian oleh Naik ini didukung oleh penelitian sebelumnya, yaitu ada hubungan antara volume perdagangan dan volatilitas yang bersifat positif (Sutrisno, 2017).Safitri dkk. (2017) juga mengungkapkan bahwa hubungan pergerakan harga dengan volume secara langsung adalah positif. Belhaj dan Ezzedine (2015) juga menemukan bahwa pada kondisi tertentu, terdapat hubungan positif yang kuat antara volume perdagangan dan volatilitas. Hal ini juga didukung oleh temuan Hsieh (2014), yaitu terdapat hubungan sebab akibat antara volume perdagangan dengan volatilitasyang signifikan pada pasar. Girard dan Omran (2009) juga memaparkan bahwa volume cenderung (rata-rata) berhubungan positif dengan volatilitas. Namun, berbeda dari temuan-temuan penelitian lainnya, Priana dan Muliartha (2017) mengungkapkan adanya pengaruh negatif volume perdagangan terhadap 
volatilitas. Perbedaan temuan penelitian terdahulu menjadi celah bagi penelitian ini untuk menguji kembali hubungan antara volume perdagangan dan volatilitas.

Studi empiris yang menguji hubungan antara volume perdagangan dan volatilitas tersebut cenderung dilakukan pada satu pasar, sehingga dalam penelitian ini akan dilakukannya perbandingan hubungan kedua variabel tersebut pada dua jenis pasar yang berbeda (emerging dan developed market) secara mengkhusus. Penelitian dilakukan dengan tujuan, yaitu mengetahui pengaruh volume perdagangan terhadap volatilitas di pasar saham Indonesia dan Amerika Serikat serta mengetahui perbedaan volatilitas dan volume perdagangan di dua pasar yang berbeda. Simpulan penelitian diharapkan menjadi penyempurnaan penelitian terdahulu yang sejenis dan menjadi pertimbangan bagi penelitian yang akan dilakukan serta pertimbangan bagi para pelaku pasar dalam memutuskan perilaku investasi yang tepatketika berinvestasi pada pasar negara berkembang dan maju.

Investasi merupakan kegiatan yang memberdayakan dana atau aset saat ini demikeuntungan dan kehidupan yang lebih layak di masa depan. Orang-orang yang melakukan kegiatan menanam modal biasa disebut investor (Halim, 2005:15).Investormemiliki tujuan utama, yaitu berdagang, memperoleh dividen, dan penyertaan kepemilikan perusahaan (Situmeang, 2015). Terdapat beberapa tahap dalam menjalankan proses investasi, yaitu menentukan tujuan, melakukan analisis, membentuk portofolio, mengevaluasi kinerja, dan merevisi kinerja (Husnan, 2015:47). Investasi dapat dilakukan di pasar modal. Berdasarkan ketersediaan informasinya pasar modal terdiri dari pasar efisien kuat mencakup 
Ni Putu Ayu Supriati, Pengaruh Volume Perdagangan...

seluruh informasi, setengah kuat mencakup informasi masa lalu dan sekarang, sedangkan bentuk lemah mencakup informasi masa lalu saja. Efisiensi pasar terjadi karena informasi yang ada di pasar dapat terserap dengan cepat dan menjadi simetris, Hartono (2016:616). Indonesia memiliki BEIdan merupakan pasar modal yang masih berkembang, sedangkanpasar modalyang pertama dan maju di dunia adalah Bursa Efek di Amerika Serikat bernama New York Stock Exchange. Terdapat beberapa jenis aset yang dapat diinvestasikan di pasar modal, salah satunyabernama saham. Definisi dari saham adalah tanda kepemilikan ekuitasoleh investor dalam suatu perusahaan (Fakhruddin, 2013:173). Saham dapat dinilai melalui harga saham yang merupakan indikator penting bagi investor (Sidqi dan Prabawani, 2017). Harga saham yang dicerminkan pada penutupan bursa disebut harga saham penutupan.Ringkasan harga dapat diklasifikasikan dengan menggunakan indeks harga saham. Fabozzi dan Harry (2011:222) menyebutkan bahwaada beberapa jenisindeks yang dibagi menjadi tiga kategori, yaitu pertama indeks yang dihasilkan oleh pasar atau system dalam pasar, kedua indeks yang dibentuk oleh organisasi tertentu dengan pemilihan saham secara subjetif, dan yang terakhir adalah indeks yang disusun berdasarkan nilai kapitaisasi pasar saham bersangkutan. Indeks yang digunakan dalam penelitian ini adalah indek pertama yang merupakan indeks seluruh harga saham pada suatu pasar, sehingga saham yang kapitalisasinya kecil tetapi likuid juga tetap terwakili. Indeks jenis ini biasa disebut sebagai indeks hargagabungan (Samsul, 2006:179). Bursa Efek Indonesia memiliki indeks gabungan yang disingkat menjadi IHSG atauJakarta Composite Index, sedangkan di NYSE disebut New York Composite 
Index.Harga saham tidak selalu sama setiap waktunya dan mengalami fluktuasi (volatilitas).

Volatilitas merupakan ukuran tinggi rendahnya fluktuasi aset pada periode tertentu. Volatilitas saham mencerminkan tingkat risiko yang dihadapi investor baik sekarang atau di masa mendatang (Purbawati, 2016).Volatilitas terbagi menjadi beberapa jenis berdasarkan penyebab terjadinya, yaitu volatilitas yang bersifat sementara dan volatilitas yang terjadi karena faktor alami (Rohmawati, 2016), sedangkan berdasarkan waktunya, volatilitas terbagi menjadi tiga jenis, yaitu volatilitas masa lalu, volatilitas yang diaplikasikan dalam model teoretis harga, dan volatilitas masa depan yang diramalkan (Suwanda, 2011:134). Pelaku pasar yang melakukan kegiatan investasi di Bursa Efek memerlukan volatilitas indeks harga saham, karena volatilitas tersebut dapat mencerminkan nilai portofolio yang mereka miliki (Katti, 2014). Hal ini juga sesuai dengan temuan Olsen (2012), investor cenderung mengekstrapolasi pergerakan pasar jangka pendek untuk dijadikan bahan pengambilan keputusan di masa depan dan adanya persepsi investor mengenai hubungan terbalik risiko-return yang menyebabkan adanya volatilitas. Pergerakan harga erat kaitannya dengan volume perdagangan, sehingga volume disebut sebagai cerminan reaksi pasar (Wahyuliantini, 2016). Volume perdagangan ini merupakan reaksi dari pengumuman berupa laporan akuntansi dan non akuntasi dari perusahaan tiap periodenya (Krisna, 2016).

Volume perdaganganmerupakan unsur kunci dalam melakukan prediksi terhadap pergerakan harga saham yang mana volume perdagangan inidapat dikomposisikan menjadi dua komponen, yaitu number of trades (number of 
Ni Putu Ayu Supriati, Pengaruh Volume Perdagangan...

transactions/trading frequency/frequency oftrade) dan the average size of each trades (size of trades/trade size) (Hardle et al., 2009:387). Volume perdagangan dapat memberikan signal bagi pergerakan harga karena volume adalah bagian dari informasi yang bersifat penting (Mahajan dan Singh, 2008). Volume perdagangan dapat dilihat darijumlah lembar saham yang diperjualbelikanpada suatu pasar dalam jangka waktu tertentu (Surya, 2016).

Keputusan investasi erat kaitannya dalam memahami kondisi dan pergerakan pasar. Pemahaman kondisi pasar dilakukan dengan analisis fundamental dan teknikal.Analisis teknikalberfokus pada studi pasar berdasarkan permintaan dan penawaran di pasar. Selain itu dalam analisis teknikal terdapat asumsi yang dipercaya oleh para analis, yakni adanya waktu yang dibutuhkan dalam menyesuaikan harga saham (speed of adjustment). Penyesuaian harga saham ini biasanya memerlukan waktu yang lama untuk mencapai harga keseimbangan yang baru sampai informasi tersebut benar-benar telah diserap oleh pasar. Waktu penyerapan informasi dapat menjadi sebuah tren pada pasar yang terjadi karena asimetri informasi. Adanya kegiatan jual beli oleh pihak-pihak yang telah lebih dahulu menerima informasi selama proses penyerapan informasi menyebabkan volatilitas terjadi (Tandelilin, 2017:400). Informasi yang asimetri dapat diminimalisir. Kerangka teori signal menjelaskan bahwa bagaimana seharusnya perusahaan memberikan informasi kepada pihak luar. Informasi ini diberikan demi meminimalisasi adanya informasi yang terjadi tidak simetri antara manajemen internal dan para pelaku pasar (Brigham dan Houston, 2014:184). 
Teori yang dianut dalam analisis teknikal ini membuktikan bahwa volume perdagangan memiliki efek terhadap volatilitas saham di pasar. Penelitian terdahulumenyebutkan bahwa volume perdagangan mengandung informasi yang dicerminkan melalui harga saham, kecuali pada pasar efisien bentuk kuat karena pada kondisi tersebut informasi pribadi tidak tercermin dalam harga saham (Mahajan dan Singh, 2009).Adanya hubungan antara volume perdagangan dan volatilitas ini juga dikemukakan peneliti Girard, Eric dan Mohammed Omran (2009), bahwa bila total volume disertakan dalam spesifikasi varians bersyarat, volume cenderung (rata-rata) berhubungan positif dengan volatilitas.Ada hubungan sebab akibat, di mana volume perdagangan menyebabkan volatilitas saham pada pasar domestik (Hsieh, Hui-Ching Sana, 2014). Volume perdagangan dan harga saham merupakan indikator awal dalam pembuatan keputusan investasi dan keduanya memiliki hubungan yang erat (Karpio et al., 2012). Eratnya hubungan ini dapat menggambarkan pengembalian dan risiko yang terjadi. Faktor harga dan volume memang berperan dalam menjelaskan beberapa pola pengembalian (Sehgal dan Vasishth, 2015).Temuan ini didukung juga oleh hasil penelitian Azuradkk. (2018) bahwa terdapat beberapa faktor yang dapat memengaruhi volatilitas, salah satunya volume perdagangan di pasar. Penelitian terbaru juga mengungkapkan hal serupa, yaitu volume perdagangan memiliki hubungan yang positif signifikan terhadap volatilitas, sehingga menyiratkan bahwa volume perdagangan menjadi faktor penting dalam menjelaskan volatilitas di pasar (Naik et al.,2018). Berdasarkan rangkuman penelitian pendukung, maka dapat dirumuskan hipotesis pertama, yaitu: 
Ni Putu Ayu Supriati, Pengaruh Volume Perdagangan...

$\mathrm{H}_{1}$ : Volume perdagangan berpengaruh positif terhadap volatilitas di pasar saham.

Studi mengenai volatilitas ini dilaksanakan di dua negara yang berbeda, yaitu pasar berkembang (emerging market) dengan pasar maju (developed market). Hasil penelitian sebelumnya menunjukkan adanya perbedaan hasil pengujian di dua jenis negara tersebut. Selain penelitian tersebut, Song et al. (2005) menemukan adanya hubungan antara volume perdagangan dan volatilitas di pasar China tetapi penyebab hubungan kedua variabel berbeda dari hasil temuan di pasar Amerika Serikat. Eaves dan Valero (2009) mengonfirmasi adanya volatilitas di pasar Tokyo.Joshi dan Kiran (2012) mengungkapkan temuan mereka yang menguji volatilitas di pasar India dan Kanada, yaituterdapat volatilitas di kedua pasar saham. Namun,volatilitas di pasar saham Kanada sedikit lebih tinggi dari pasar saham India. Hasil temuan Agarwal (2017) mengungkapkan bahwa terdapat volatilitas di pasar negara berkembang dan negara maju secara umum dengan menggunakan indeks MSCI, namun volatilitas hari sebelumnya memiliki pengaruh yang lebih besar dalam menjelaskan volatilitas hari ini di pasar berkembang, sementara di pasar maju, volatilitas sebelumnya dan informasi memiliki pengaruh yang besar dalam menjelaskan volatilitas hari ini. Volatilitas disebabkan oleh faktor umum, bukan faktor spesifik negara, namun hal ini tidak selalu terjadi. Komponen umum ini lebih stabil di negara-negara Eropa dan Amerika Latin daripada di wilayah Asia-Pasifik dan Afrika (Mobarek dan Michelle, 2014). Ada hubungan umpan balik antara volume perdagangan dan volatilitas, yang mana hasildi Malaysia, Filipina, Singapura dan Thailand memiliki hubungan saling memengaruhi yang sangat berkorelasi tinggi, namun di 
Jepang memiliki korelasi yang lebih rendah (Hsieh, Hui-Ching Sana, 2014). Perbedaan lainnya juga ditemukan oleh Naik dan Reddy (2016) yang mengungkapkan bahwa indeks volatilitas di Amerika Serikat (US VIX) adalah indeks yang paling berpengaruh terhadap indeks volatilitas negara lainnya, yaitu Jerman, India, Korea Selatan, dan China. Berdasarkan penjabaran temuan praktis, maka hipotesis kedua:

$\mathrm{H}_{2}$ :Ada perbedaan volume perdagangan dan volatilitas di pasar negara berkembang dan pasar negara maju.

\section{METODE PENELITIAN}

Desain penelitian merupakan rencana procedural dan panduan bagi peneliti. Desain penelitian ini bermanfaat mengarahkan kerja peneliti dalam menjawab petanyaan-pertanyaan secara valid, objektif, dan akurat serta penelitian dapat lebih efektif dan efisien (Rahyuda, 2016:104). Penelitian ini dilakukan sesuai dengan desain penelitian kausal komparatif. Desain kausalitas adalah penelitian yang meneliti adanya pengaruh yang bersifat sebab akibat pada beberapa variable, sedangkan komparatif adalah penelitian yang dilakukan dengan membandingkan variabel pada sampel berbeda (Kuncoro, 2009:17). Lokasi penelitian adalah BEIserta NYSEpada periode 2013-2018. Data dapat diakses diwww.idx.co.id untuk pasar berkembang dan www.finance.yahoo.comuntuk pasar maju.Objek dalam penelitian merupakan karakteristik objek yang dipelajari oleh peneliti (Sugiyono, 2013). Peneliti menjadikan volatilitas sebagai objek dan dapat dihitung berdasarkan harga saham penutupan dalam periode harian pada IHSGdi BEI dan NYSEperiode 2013-2018. Variabel bebas (independen) yang digunakan adalah volume perdaganganatau jumlah lembar saham dalam periode bulanan yang 
Ni Putu Ayu Supriati, Pengaruh Volume Perdagangan...

diperjualbelikan, sedangkan volatilitas menjadi variabel terikat. Volume perdagangan dalam penelitian terbagi menjadi dua, yaitu volume perdagangan Jakarta Composite Index $\left(\mathrm{X}_{1}\right)$ dan volume perdagangan New York Composite Index $\left(\mathrm{X}_{2}\right)$. Volatilitas dalam pegertian sebagai fluktuasi indeks harga saham. Volatilitas dalam penelitian terbagi menjadi dua, yaitu volatilitas Jakarta Composite Index $\left(\mathrm{Y}_{1}\right)$ dan volatilitas New York Composite Index $\left(\mathrm{Y}_{2}\right)$. Tahap-tahap yang digunakan untuk mencari volatilitas pada pasar saham sebagai berikut.

(1) Mengumpulkan data Indeks Harga Saham periode harian dengan menggunakan harga penutupan dari masing-masing pasar.

(2) Menghitung nilai capital gain (capital loss) saham yang dapat diukur dengan menggunakan rumus (Hartono, 2017:284).

$K_{m}=\frac{L \quad[-L \quad[-]}{L \quad[-1}$

Keterangan:

$$
\begin{array}{lll}
K_{m} & & =\text { Return Pasar } \\
\Pi \quad{ }_{t} & =\text { IHSG pada waktu } \mathrm{t} \\
{ }_{L} \quad{ }_{-1} & =\text { IHSG pada waktu } \mathrm{t}-1
\end{array}
$$

(3) Menghitung standar deviasi (volatilitas bulanan) dalam satuan persen dengan rumus, sebagai berikut (Hartono, 2017:307).

$\mathrm{SD}=\sqrt{\frac{\sum_{\mathrm{t}=1}^{\mathrm{N}}\left[\mathrm{X}_{\mathrm{i}}-\bar{X}\right]^{2}}{\mathrm{~N}-1}} \times 100 \%$

Keterangan:

$\mathrm{SD}=$ Volatilitas bulanan berupa nilai standar deviasi 


$$
\begin{array}{ll}
\mathrm{X}_{\mathrm{i}} & =\text { Returnsuatu saham } \\
\bar{X} & =\text { Return rata-rata } \\
\mathrm{N} & =\text { Jumlah observasi }
\end{array}
$$

Composite IndexPeriode 2013-2018 di BEI (emerging markets) dan NYSE (developed market)sebagai populasi sekaligus sampel, sehingga penentuan sampel dengannonprobably sampling dan masuk dalam teknik sampling jenuh. Pengumpulan data dilakukan dengan metode observasi nonpartisipan atau tidak langsung melibatkan peneliti (Sugiyono, 2015:235). Data penelitian termasuk jenis data kuantitatif, yaitu berupa angka dan dilengkapi satuan hitung (Sugiyono, 2016:23). Data tersebut adalah data harga saham penutupan dan volume perdagangan saham.

Analisis regresi linier adalah teknik analisis utama dalam penelitian.Analisis ini berguna dalam melihat hubungan variabel sekaligus kekuatan hubungan tersebut (Ghozali, 2016:94). Analisis regresi ini dapat dilakukan dengan pengggunaan software Statistik Ilmu Sosial atau disebut dengansingkatan SPSS. Model regresi ditunjukkan:

$\mathrm{Y}=\alpha+\beta \mathrm{Xi}+\varepsilon$

di mana,

$\mathrm{Y} \quad=$ Volatilitas

$\alpha=$ Nilai Konstanta

$\beta=$ Nilai Koefisien

$\mathrm{Xi} \quad=$ Volume perdagangan 
$\varepsilon \quad=$ Komponen pengganggu atau error term

Statistik deskriptif menyediakan jumlah data, standar deviasi, nilai maksimum, dan minimum serta rata-rata. Setelah karakteristik data diketahui, kemudian dilakukan pengujian apakah model layak digunakan atau tidak. Uji ini bernama uji asumsi klasik. Hasil regresi akan menunjukkan sebesar apa variabel bebas dapat memengaruhi variabel terikat(Ghozali, 2016:95). Nilai Adjusted $R^{2}$ dijadikan pedoman demi menghindari hasil yang bias.

Berpengaruh atau tidaknyasuatu variabel dengan variabel lain tercermin dari hasil Uji Koefisien Regresi. Apabila hasil probabilitas lebih rendah dari taraf siginifikansi $(\alpha)=5 \%$, maka ada pengaruh variabel bebas yang bersifat signifikan terhadap variabel terikat(Utama, 2016:62).Komparasi dua sampel yang bersifat independen dilakukan menggunakan uji beda t-test. Rumus dalam t-test, sebagai berikut (Hartono, 2013:213):

$$
t=\frac{x_{1}-x_{2}}{\sqrt{S_{g}^{2}\left[\frac{2}{n_{1}}-\frac{2}{n_{2}}\right]}}
$$

dengan,

$$
S_{g}^{2}=\frac{\left(n_{1}-1\right) S_{1}^{2}+\left(n_{2}-1\right) S_{L}^{Z}}{\left(n_{1}+n_{a}\right)-2}
$$

Keterangan:

$x_{1}=$ rata-rata pertama

$x_{2}=$ rata-rata kedua

$s_{1}=$ standar deviasi pertama

$s_{2}=$ standar deviasi kedua

$s_{g}^{2}=$ varian dari kedua sampel 
E-Jurnal Manajemen, Vol. 8, No. 4, 2019: 2438 - 2465

$$
\begin{aligned}
& n_{1}=\text { observasi pasar pertama } \\
& n_{2}=\text { observasi pasar kedua }
\end{aligned}
$$




\section{HASIL DAN PEMBAHASAN}

\section{Tabel 1.}

\section{Hasil Statistik Deskriptif}

\begin{tabular}{llllll}
\hline & $\mathrm{N}$ & Minimum & Maksimum & Rata-rata & Std. Deviasi \\
\hline $\mathrm{Y}_{1}$ & 60 & 0,36 & 2,57 & 0,8969 & 0,45621 \\
$\mathrm{X}_{1}$ & 60 & $723.336 .100,00$ & 150.673 .112 .600 & 57.322 .589 .673 & 36.424 .116 .590 \\
$\mathrm{Y}_{2}$ & 60 & 0,26 & 1,56 & 0,6978 & 0,30706 \\
$\mathrm{X}_{2}$ & 60 & $58.131 .140 .000,00$ & 93.694 .040 .000 & 73.940 .966 .333 & 8.404 .081 .478 \\
\hline \multicolumn{5}{l}{ Sumber : Data dianalisis, 2018.}
\end{tabular}

Berdasarkan Tabel 1, jumlah sampel yang diteliti adalah 60 data volatilitas bulanan sebagai variabel $\mathrm{X}$ denganrata-rata sebesar0,8969 persen untuk BEI dan 0,6978 persen untuk NYSE.Volatilitas terendah selama periode pengamatan di BEI sebesar 0,36 persen dan tertinggi sebesar 2,57 persen. Standar deviasi untuk volatilitas di BEI adalah sebesar 0,45621 persen. Hal ini menunjukkan bahwa terjadi perbedaan nilai volatilitas IHSG yang diteliti terhadap nilai rata - rata sebesar 0,45621 persen. Berbeda halnya dengan di NYSE bahwa volatilitas terendah selama periode pengamatan sebesar 0,26 persen dan tertinggi sebesar 1,56 persen. Standar deviasi untuk volatilitas adalah sebesar 0,30706 persen. Hal ini menunjukkan bahwa terjadi perbedaan nilai volatilitas yang diteliti terhadap nilai rata - rata sebesar 0,30706 persen.

Selain variabel $\mathrm{Y}$, terdapat pula variabel $\mathrm{X}$ yang merupakan variabel Volume perdagangan. Volume perdagangan indeks harga saham gabungan di BEI dan NYSE menunjukkan jumlah sampel adalah 60 data volume perdagangan secara bulanan. Volume perdagangan saham di Bursa Efek Indonesia menunjukkan nilai rata-rata sebesar 57.322.589.673,00. Angka tersebut menunjukkan bahwa perusahaan yang tercatat memperdagangkan sahamnya sebanyak rata-rata 57.322.589.673 lembar. Hasil tersebut berbeda dengan New 
York stock Exchange, di mana volume perdagangan di pasar ini menunjukkan nilai rata-rata sebesar 73.940.966.333,00, maka secara rata-rata perusahaanmampu memperdagangkan sahamnya sebanyak 73.940.966.333 lembar.Nilai minimum volume perdagangan di BEI sebesar 723.336.100 lembar saham pada Juni 2017, sedangkan nilai maksimum sebesar 150.673.112.600 lembar saham pada November 2016. Standar deviasi untuk volume perdagangan saham di BEI adalah sebesar 36.424.116.590,00. Jumlah tersebut tidak sama seperti di NYSE, di mana nilai minimum volume perdagangan sebesar 58.131.140.000 lembar saham pada Agustus 2014, sedangkan nilai maksimum sebesar 93.694.040.000 lembar saham pada Oktober 2014. Standar deviasi untuk volume perdagangan saham di NYSE ini adalah sebesar8.404.081.478,00.

Tabel 2.

Hasil Uji Normalitas (Jakarta Composite Index)

\begin{tabular}{llr}
\hline & & Unstandardized Residual \\
Normal Parameters & & 60 \\
& Mean & 0,0000000 \\
Most Extreme Differences & Std. Deviation & 0,40686023 \\
& Absolute & 0,085 \\
& Positive & 0,085 \\
Kolmogorov - Smirnov Z & Negative & $-0,070$ \\
Asymp. Sig. (2-tailed) & & 0,085 \\
Sumber $:$ Data dianalisis, 2018 & & $0,200^{\text {c,d }}$ \\
\hline
\end{tabular}
Sumber :Data dianalisis, 2018.

Tabel 3.

Hasil Uji Normalitas (New York Composite Index)

\begin{tabular}{llr}
\hline & & Unstandardized Residual \\
\hline N & & 60 \\
Normal Parameters & Mean & 0,0000000 \\
& Std. Deviation & 0.22648787 \\
Most Extreme Differences & Absolute & 0,061 \\
& Positive & 0,061 \\
& Negative & $-0,042$ \\
Kolmogorov - Smirnov Z & & 0,061 \\
Asymp. Sig. (2-tailed) & & $0,200^{\text {c,d }}$ \\
\hline Sumber $:$ Data dianalisis, 2018 & &
\end{tabular}


Ni Putu Ayu Supriati, Pengaruh Volume Perdagangan...

Kolmogorov Smirnovadalah jenis uji normalitas yang dipilih sebagai metode pengujian dalam penelitian. Model regresi dikatakan layak dilanjutkan jika data berdistribusi normal taraf siginifikansi yang disyaratkan lebih kecil dibandingkan angka Asymp. Sig (2 tailed) pada tabel. Hasil uji Kolmogrov-Smirnov untuk data dari BEI maupun NYSE adalah 0,200, sehingga data yang dianalisis di kedua pasar berdistribusi secara normal.

Uji autokolerasi dalam model regresi yang dipilih adalah uji Durbin-Watson (DW). Hasil uji autokolerasi tercantum dalam Tabel 4 untuk Jakarta Composite Indexdan Tabel 5 untuk New York Composite Index.

Tabel 4.

Hasil Uji Autokolerasi (Jakarta Composite Index)

\begin{tabular}{llrrrrr}
\hline \multicolumn{1}{c}{ Model } & $\mathrm{R}$ & $\mathrm{R}$ Square & $\begin{array}{c}\text { Adjusted R } \\
\text { Square }\end{array}$ & $\begin{array}{c}\text { Std. Error of the } \\
\text { Estimate }\end{array}$ & $\begin{array}{c}\text { Durbin- } \\
\text { Watson }\end{array}$ \\
\hline 1 & $0,278^{\mathrm{a}}$ & 0,077 & 0,061 & 0,44203 & 2,198 \\
\hline Sumber: Data dianalisis, 2018. & & & &
\end{tabular}

Tabel 5.

Hasil Uji Autokolerasi (New York Composite Index)

\begin{tabular}{|c|c|c|c|c|c|}
\hline Model & $\mathrm{R}$ & R Square & $\begin{array}{c}\text { Adjusted R } \\
\text { Square }\end{array}$ & $\begin{array}{l}\text { Std. Error of the } \\
\text { Estimate }\end{array}$ & $\begin{array}{l}\text { Durbin- } \\
\text { Watson }\end{array}$ \\
\hline 1 & $0,675^{\mathrm{a}}$ & 0,456 & 0,447 & 0,22843 & 1,743 \\
\hline
\end{tabular}

Nilai Durbin-Watson pada data Jakarta Composite Index sebesar 2,198 dengan angka durbin lower sebesar 1,548 dan durbin upper1,616. Begitu pula pada Tabel 5, terdapat hasil pengujian autokorelasi pada New York Composite Indexsebesar 1,743. Nilai Durbin-Watson (DW)ini berada di antara durbin upper dan 4-durbin upper. Hal ini memiliki arti bahwa tidak ada gejala autokorelasi pada model, sehingga model layak digunakan dalam pengujian. 
Pengaruh volume perdagangan terhadap volatiltas dilihat dari hasil analisis regresi linier pada Tabel 6 danTabel 7.

Tabel 6.

Hasil Uji Analisis Regresi Linier (Jakarta Composite Index)

\begin{tabular}{|c|c|c|c|c|c|}
\hline \multirow{2}{*}{ Variabel } & \multicolumn{2}{|c|}{$\begin{array}{l}\text { Unstandardized } \\
\text { Coefficients }\end{array}$} & \multirow{2}{*}{$\begin{array}{l}\text { Standardized } \\
\text { Coefficients } \\
\text { Beta }\end{array}$} & \multirow{2}{*}{$\mathrm{T}$} & \multirow{2}{*}{ Sig. } \\
\hline & $\mathrm{B}$ & $\begin{array}{l}\text { Std } \\
\text { Error }\end{array}$ & & & \\
\hline (Constant) & 0,698 & 0,107 & & 6,516 & 0,000 \\
\hline $\begin{array}{l}\text { Volume Perdagangan Jakarta } \\
\text { Composite Index }\left(\mathrm{X}_{1}\right)\end{array}$ & $3.478 \mathrm{E}-12$ & 0,000 & 0,278 & 2,201 & 0,032 \\
\hline$F_{\text {hitung }}$ & $=4,846$ & & & & \\
\hline Sig. $F_{\text {hitung }}$ & $=0,032$ & & & & \\
\hline Adjusted R Square & $=0,061$ & & & & \\
\hline
\end{tabular}

Tabel 7.

Hasil Uji Analisis Regresi Linier (New York Composite Index)

\begin{tabular}{|c|c|c|c|c|c|}
\hline \multirow{2}{*}{ ariabel } & \multicolumn{2}{|c|}{$\begin{array}{l}\text { Unstandardized } \\
\text { Coefficients }\end{array}$} & \multirow{2}{*}{$\begin{array}{l}\text { Standardized } \\
\text { Coefficients }\end{array}$} & \multirow{2}{*}{$\mathrm{T}$} & \multirow{2}{*}{ Sig. } \\
\hline & B & $\begin{array}{l}\text { Std. } \\
\text { Error }\end{array}$ & & & \\
\hline (Constant) & $-1,126$ & 0,263 & & $-4,278$ & 0,000 \\
\hline $\begin{array}{l}\text { Volume Perdagangan New } \\
\text { York Index }\left(\mathrm{X}_{2}\right)\end{array}$ & $2.467 \mathrm{E}-11$ & 0,000 & 0,675 & 6,972 & 0,000 \\
\hline $\mathrm{F}_{\text {hitung }}$ & $=48,606$ & & & & \\
\hline Sig. $F_{\text {hitung }}$ & $=0,000$ & & & & \\
\hline Adjusted $R$ Square & $=0,447$ & & & & \\
\hline
\end{tabular}

Sumber:Data dianalisis, 2018

Berdasarkan Tabel 6, Adjusted $R$ Square $\left(\mathrm{R}^{2}\right)$ menunjukkan bahwa 6,1\% variasi volume perdagangan memengaruhi variasi volatilitas di Bursa Efek Indonesia, sedangkan Tabel 7 memperlihatkan bahwa pengaruh variasi volume 
Ni Putu Ayu Supriati, Pengaruh Volume Perdagangan...

sebesar44,7\% terhadap variasi volatilitas di New York Stok Exchange. Hasil pengujian statistik di Bursa Efek Indonesia mengindikasikannilai koefisien volume perdagangan adalah3.478E-12 dengan signifikansi 0,032 . Berbeda halnya dengan hasil pengujian statistik di New York Stock Exchange, yaitu nilai koefisien volume perdagangan adalah2.467E-11 dengan tingkat yang sangat siginifikan sebesar 0,000. Angka signifikansi kedua pasar yang lebih rendah dari taraf siginifikansi sebesar 0,05 memperkuat temuan bahwavolume perdagangan berpengaruh positifsignifikan terhadap volatilitas. Adanya efek dari volume perdagangan terhadap volatilitas di kedua pasar menyebabkan hipotesis pertama dapat dibuktikan.

Volume perdagangan merupakan cerminan reaksi pasar terhadap pemberiansignalatau informasi dari pihak perusahaan kepada investor. Namun, informasi tersebut tidak tersebar secara merata, maka hal ini menunjukkan adanya asimetri informasi. Interpretasi informasi yang dilakukan investor juga menjadi berbeda sejalan dengan berapa banyak signal yang berhasil diperoleh dan dianalisis oleh investor serta bergantung pada kemampuan analisis dari investor itu sendiri. Perbedaan interpretasi atau respon oleh investor inilah yang menyebabkan keputusan investasi masing-masing investor juga berbeda dan berpengaruh pada naik turunnya penawaran dan permintaan saham di pasar. Perubahan permintaan dan penawaran ini menyebabkan perubahan volume perdagangan di pasar yang berpengaruh pada tinggi rendahnya volatilitas. Apabila volume perdagangan tinggi, maka pasar menjadi lebih volatil dan begitu juga sebaliknya. 
Berdasarkan hal tersebut, diperlukan distribusi informasi yang merata kepada para investor. Informasi yang menjadi signal dari perusahaan ini dapat berupa laporan keuangan dan laporan non-akuntansi. Signal ini memberikan motivasi bagi investor untuk mengambil langkah keputusan investasi yang tepat, apakah akan membeli, menjual, atau mempertahankan sahamnya. Apabila investor menangkap signal positif dari pasar, maka investor akan cenderung tetap mempertahankan posisi saham yang mereka miliki. Keadaan mempertahankan saham ini tentu akan menyebabkan volume perdagangan menjadi lebih stabil karena lembar saham yang diperdagangkan stabil dan akhirnya menyebabkan volatilitas pasar menjadi lebih stabil pula. Volatilitas ini mencerminkan pasar yang lebih stabil dan risiko-return dapat diramalkan dengan tepat. Volatilitas inilah yang kemudian akan menjadi signal yang tepat untuk investor gunakan dalam meramalkan pergerakan pasar berikutnya.

Temuan ini dapat mendukung penelitian yang telah dilaksanakan secara umum atau khusus di pasar-pasar lainnya, yaitu penelitian oleh Girard, Eric dan Mohammed Omran (2009) di pasar saham Mesir, Hsieh, Hui-Ching Sana (2014) di pasar negara-negara Asia, Belhaj dan Ezzedine (2015) di pasar Tunisia, Safitri dkk. (2017) di pasar Indonesia, Azuradkk. (2018) di pasar Indonesia dan Naik et al.(2018) di pasar Afrika Selatan yang mengemukakan bahwa volume perdagangan berpengaruh terhadap volatilitas. 
Tabel 8.

Hasil Uji Beda Dua Rata-Rata

\begin{tabular}{|c|c|c|c|c|c|c|c|c|}
\hline & & \multicolumn{2}{|c|}{$\begin{array}{l}\text { Levene's Test } \\
\text { for Equality } \\
\text { of Variances }\end{array}$} & \multirow[b]{2}{*}{$\mathrm{T}$} & \multicolumn{3}{|c|}{ t-test for Equality of Mean } & \multirow[b]{2}{*}{$\begin{array}{l}\text { Std. Error } \\
\text { Difference }\end{array}$} \\
\hline & & $\mathrm{F}$ & Sig. & & Df & $\begin{array}{c}\text { Sig. } \\
\text { (2-tailed) }\end{array}$ & $\begin{array}{c}\text { Mean } \\
\text { Difference }\end{array}$ & \\
\hline \multirow[t]{2}{*}{$\begin{array}{l}\text { Un } \\
\text { standar } \\
\text { dized } \\
\text { Residual }\end{array}$} & $\begin{array}{l}\text { Equal } \\
\text { variances } \\
\text { assumed }\end{array}$ & 3.074 & 0,082 & 3,676 & 118 & 0,000 & 0,24960979 & 0,06790694 \\
\hline & $\begin{array}{l}\text { Equal } \\
\text { variances } \\
\text { not } \\
\text { assumed }\end{array}$ & & & 3,676 & 102,4 & 0,000 & 0,24960979 & 0,06790694 \\
\hline
\end{tabular}

Hasil uji beda pada Tabel 8 diperoleh dengan angka signifikansi sebesar 0,000. Hasil ini berada di bawah taraf signifikansi yang disyaratkan yaitu 0,05 , sehingga data yang dianalisis memiliki perbedaan yang signifikan yang berarti memang ada perbedaan volatilitas dan pengaruh volume perdagangan terhadap volatilitas pada pasar berkembang seperti Indonesia dan maju seperti Amerika Serikat.Perbedaan dapat dilihat dari rata-rata volume perdagangan di Bursa Efek Indonesia yang lebih rendah dibandingkan New York Stock Exchange. Hal ini dipengaruhi oleh beberapa faktor, seperti New York Stock Exchange yang telah mencatatkan 2.400 perusahaan dan jumlah ini jauh lebih banyak daripada di Bursa Efek Indonesia, yaitu hanya 559 perusahaan. Hal ini berpengaruh pada banyak atau sedikitnya kegiatan perdagangan di pasar. Perbedaan rata-rata volume perdagangan juga dipengaruhi oleh kemampuan investor di pasar berkembang dan pasar maju yang berbeda dalam melakukan kegiatan investasi.

Volatilitas IHSG terjadi di kedua jenis pasar, namun volatilitas di Bursa Efek Indonesia lebih tinggi dibandingkan volatilitas di New York Stock Exchange. 
Perbedaan ini dapat dipengaruhi oleh budaya di kedua negara, yaitu perilaku investor dengan pemahaman mengenai investasi saham yang berbeda, stabilitas kondisi perekonomian yang berbeda antara pasar berkembang dan pasar maju, serta faktor-faktor lain seperti suku bunga dan inflasi yang memengaruhi pasar. Temuan ini juga mengindikasikan bahwa asimetri informasi lebih besar terjadi di pasar saham Indonesia dibandingkan dengan pasar saham New York. Volatilitas saham yang tinggi sesungguhnya bukan kondisi buruk bagi suatu pasar dan dapat dimanfaatkan sebagai peluang oleh investor untuk meraih return yang lebih tinggi.

Pengaruh volume perdagangan terhadap volatilitas di Indonesia memiliki persentase yang lebih rendah dibandingkan pengaruh volume perdagangan terhadap volatilitas di Amerika Serikat. Hal ini terjadi mengingat Indonesia merupakan negara yang masih berkembang, sehingga stabilitas kondisi perekonomian, khususnya perdagangan saham masih rendah dan pasar negara berkembang seperti Indonesia masih dipengaruhi banyak faktor selain volume perdagangan dibandingkan pasar negara maju seperti Amerika Serikat. Hal ini menyebabkan tinggi rendahnya volatilitas menjadi berbeda. Selain itu, perbedaan ini juga dapat disebabkan oleh perilaku investor di Indonesia yang mayoritas masih dikategorikan subjek baru dalam kegiatan investasi saham dibandingkan investor di New York, sehingga pengalaman dalam menginterpretasikan informasi masih kurang.

Penelitian terdahulu olehJoshi dan Kiran (2012), Hsieh, Hui-Ching Sana (2014), Mobarek, Asma dan Michelle Li (2014), dan Agarwal (2017) yang 
Ni Putu Ayu Supriati, Pengaruh Volume Perdagangan...

menyatakan bahwa terdapat perbedaan temuan volatilitas di pasar yang berbeda dan hal tersebut dibuktikan kembali pada penelitian ini.

Penelitian yang dilakukan dapat memberikan kontribusi dalam khasanah ilmu pengetahuan mengenai investasi saham, khususnya volatilitas saham. Volume perdagangan merupakan cerminan reaksi pasar terhadap signal yang diberikan perusahaan kepada pasar atau investor. Adanya fluktuasi volume perdagangan maka menunjukkan bahwa terjadi asimetri informasi. Asimetri informasi ini terjadi karena signal yang diberikan perusahaan kepada investor kurang merata, sehingga menyebabkan interpretasi informasi tersebut menjadi berbeda-beda oleh masing-masing investor. Volume perdagangan yang semakin tinggi menyebabkan pasar menjadi lebih volatil. Temuan ini mendukung signal theory yang menjelaskanbahwa penting bagi perusahaan dalam memberikan informasi atau signal kepada investor, sehingga asimetri informasi dapat diminimalisir. Penelitian ini membantah teori pasar efisien terutama pasar bentuk lemah, yang mana teori tersebut mengemukakan bahwa pasar menjadi efisien jika semua orang mengamati sistem informasi masa lalu yang sudah mencerminkan semua informasi. Teori pasar efisien tidak dapat dibuktikan dalam penelitian ini karena asimetri informasi masih terjadi di pasar dan informasi harga masa lalu belum mencerminkan semua informasi untuk meramalkan keuntungan di masa mendatang.

Temuan ini bisa dijadikan landasan pertimbangan bagi investor ketika melakukan pengambilan keputusan terkait kegiatan menjual atau membeli terutama di pasar negara berkembang dan maju seperti Indonesia dan Amerika 
Serikat. Penelitian ini membuktikan bahwa volume perdagangan dapat menjadi salah satu faktor penting dalam meramalkan volatilitas di suatu pasar. Tinggi rendahnya volatilitas dapat menjadi pedoman bagi investor dalam membuat keputusan apakah lebih tertarik dengan pasar berkembang atau pasar maju serta dengan adanya volatilitas ini dapat mencerminkan karakteristik investor itu sendiri apakah lebih menyukai investasi dengan return stabil yang mengarah pada investasi jangka panjang atau sebaliknya.

\section{SIMPULAN DAN SARAN}

Berdasarkan hasil pengujian dan analisis, maka dapat disimpulkan bahwa Volume perdagangan berpengaruh positif siginifikan terhadap volatilitas di Bursa Efek Indonesia dan New York Stock Exchange. Peningkatan kegiatan jual beli di pasar modal menyebabkan kenaikan volume perdagangan, sehingga berpengaruh pada volatilitas pasar. Volatilitas pasar yang tinggi tidak selamanya merupakan kondisi yang buruk, hal ini merupakan suatu peluang yang dapat dimanfaatkan oleh investor untuk mendapatkan return yang tinggi pula di masa mendatang. Terdapat perbedaan volume perdagangan dan volatilitas di kedua pasar, yaitu Bursa Efek Indonesia dan New York Stock Exchange Hal ini dipengaruhi oleh beberapa faktor, terutama pola perilaku investor dan kondisi perekonomian negara.

Berdasarkan hasil penelitian dan kesimpulan maka penulis merekomendasikan saran, yaitu volatilitas adalah faktor penting yang dapat digunakan oleh investor sebagai pertimbangan dalam membuat keputusan investasi yang tentunya dengan memerhatikan volume perdagangan sebagai 
Ni Putu Ayu Supriati, Pengaruh Volume Perdagangan...

cerminan informasi di pasar. Volatilitas pada suatu pasar dapat dijadikan pedoman bagi investor dalam melihat potensi pasar dan perusahaan dalam memberikan capital gain yang maksimal sesuai dengan risiko yang mampu dihadapi oleh investor. Volatilitas yang tinggi mencerminkan risiko yang tinggi, namun disertai dengan peluang memeroleh return yang besar, sedangkan volatilitas yang stabil mencerminkan risiko yang rendah dengan potensi return tertentu. Investor dapat memilih pasar yang sesuai dengan karakteristik mereka dalam berinvestasi. Peneliti selanjutnya disarankan menggunakan variabel independen lain yang dapat memengaruhi volatilitas, seperti suku bunga, inflasi, dan nilai tukar. Peneliti selanjutnya juga dapat melakukan pengujian komparasi pada pasar lainnya sebagai lokasi penelitian.

\section{DAFTAR REFERENSI}

Agarwal, Sonali. (2017).Volatility in Stock Markets: A Comparison of Developed and Emerging Markets of The World.Indian Journal of Commerce \& Management Studies, 8(2), 87-92.

Azura, Nur Syarifah, Myrna, dan Nurhasanah. (2018). Faktor - Faktor yang Mempengaruhi Volatilitas Harga Saham pada Perusahaan Manufaktur yang Tercatat di Bursa Efek Indonesia Tahun 2012-2016. www.repository.umrah.ac.id. (diakses pada 2 Juli 2018)

Belhaj, Fethi dan Ezzeddine Abaoub. (2015). A Generalized Autoregressive Conditional Heteroskedasticity Examination of the Relationship between Trading Volume and Conditional Volatility in the Tunisian Stock Market: Evidence for the Information Flow Paradigm. International Journal of Economics and Financial Issues, 5 (2), 354-364.

Eaves, James dan Magali Valero. (2009). Differences in Opinions and The Volatility-Volume Relationship on The Tokyo Grain Exchange. Agricultural Finance Review, 69(2), 180-195

Eugene, Brigham dan Houston Joel. (2014). Dasar-dasar Manajemen Keuangan Jakarta: Salemba Empat. 
Fabozzi, Frank J dan Harry M. Markowitz. (2011). The Theory and Practice of Investment Management: Asset Allocation, Valuation, Portfolio

Construction, and Strategies Hardcover. New Jersey: John Wiley \& Sons.

Fakhruddin, Hendy M. (2013). Istilah Pasar Modal A-Z. Jakarta: PT Gramedia.

Girard, Eric dan Mohammed Omran. (2009). On the Relationship Between Trading Volume and Stock Price Volatility in CASE. International Journal of Managerial Finance, 5 (1), 110-134.

Ghozali, Imam. (2016). Aplikasi Analisis Multivariate dengan Program IBM SPSS 23. Semarang: Badan Penerbit Universitas Diponegoro.

Halim, Abdul. (2005). Manajemen Keuangan Bisnis (Konsep dan Aplikasinya). Jakarta: Mitra Wacana Media.

Hardle, W.K., Nikolaus, dan Ludger. (2009). Applied Quantitative Finance. Berlin: Spinger Berlin Heidelberg.

Hartono, Jogiyanto. (2013). Metodologi Penelitian Bisnis (Salah Kaprah dan Pengalaman-pengalaman) Edisi 6. Yogyakarta: BPFE-Yogyakarta.

Hartono, Jogiyanto. (2017). Teori Portofolio dan Analisis Investasi (Edisi Kesebelas). Yogyakarta: BPFE-Yogyakarta.

Husnan, Suad. (2015). Dasar-Dasar Teori Portofolio dan Analisis Sekuritas. Yogyakarta: UPP STIM YKPN

Hsieh, Hui-Ching Sana. (2014). The Causal Relationships Between Stock Returns, Trading Volume, and Volatility Empirical Evidence from Asian Listed Real Estate Companies. International Journal of Managerial Finance, 10 (2), 218-240.

Joshi, Prashant dan Kiran Pandya. (2012).Volatility in Stock Market of India and Canada.The IUP Journal of Applied 78 Economics, 11(4), 72-79.

Karpio, P. Łukasiewicz, danA. Orłowski.(2012). Price-Volume Relationship in Polish Stock Market. 5th Symposium on Physics in Economics and Social Sciences, 121(2-B), 61-66.

Katti, Siti W.B., (2014). Analisis Faktor Makro Ekonomi, Indeks Bursa Global, dan Kepemilikan Saham Asing Terhadap Pergerakan Harga Saham di Bursa Efek Indonesia. Jurnal Ekomaks, 3(1), 92-106. 
Krisna, Ayu. (2016). Pengaruh Volume Perdagangan Saham, Leverage, dan Tingkat Suku Bunga terhadap Volatilitas Harga Saham. E-Jurnal Akuntansi Universitas Udayana, 17(2), 1112-1140.

Mahajan, Sarika dan Balwinder Singh. (2008). An Empirical Analysis of Stock Price-Volume Relationship in Indian Stock Market. SAGE Journal, 12(3), $1-13$.

Mahajan, Sarika dan Balwinder Singh. (2009). The Empirical Investigation of Relationship between Return, Volume and Volatility Dynamics in Indian Stock Market. Eurasian Journal of Business and Economics, 2(4),113-137.

Mobarek, Asma dan Michelle Li. (2014). Regional Volatility: Common or Country-Specific? Exploration of International Stock Market. Journal Studies in Economics and Finance, 31(4), 406 - 425.

Naik, Maithili S dan Reddy. (2016). Volatility Indices: An International Comparison.The IUP Journal of Financial Risk Management,8(3), 7-19.

Naik, Pramod, Rangan Gupta, dan Puja Padhi. (2018).The Relationship Between Stock Market Volatility and Trading Volume: Evidence from South Africa.The Journal of Developing Areas, 52(1), 99 - 114.

Napitulu, Veronica dan Syahyunan. (2012). Pengaruh Return Saham, Volume Perdagangan dan Volatilitas Harga Saham terhadap Bid-Ask Spread pada Perusahaan yang Melakukan Stock Split di Bursa Efek Indonesia. Jurnal Departemen Manajemen Fakultas Ekonomi Universitas Sumatera Utara,110.

Olsen, Robert A. (2012). The Influence of Affect on Stock Price Volatility: New Theory and Evidence. Qualitative Research in Financial Markets, 4(1),26 35 .

Otok, Bambang Widjanarko, dkk. (2006). Faktor-faktor yang Mempengaruhi Volume Perdagangan Saham Menggunakan Maltivariate Adaptive Regression Splines. Jurnal Widya Manajemen dan Akuntansi, 6(3), 303316.

Priana, Korin dan Ketut Muliartha. (2017). Pengaruh Volume Perdagangan Saham, Leverage, Dan Dividend Payout Ratio Pada Volatilitas Harga Saham. E-Jurnal Akuntansi Universitas Udayana, 20(1), 1-29.

Purbawati, Ni Luh Krisna. (2016). Perbandingan Volatilitas Indeks Harga Saham Gabungan (IHSG) Sebelum dan Setelah Krisis Subprime Mortgage. EJurnal Manajemen Unud, 5(2), 1014-1042.

Rahyuda, Ketut. (2016). Metode Penelitian Bisnis. Denpasar: Udayana University Press. 
Rohmawati, Irma. (2016). Pengaruh Volume Perdagangan, Dividend Payout Ratio, Dan Inflasi Terhadap Volatilitas Harga Saham pada Perusahaan Yang Terdaftar Dalam Indeks LQ45 Tahun 2011-2015. Jurnal Skripsi. eprints.uny.ac.id (diakses pada 27 April 2018).

Safitri, Dian, dkk. (2017). Hubungan Antara Volatilitas Harga Saham dan Volume Perdagangan Saham di Bursa Efek Indonesia. Sustainable Competitive Advantage Journal, 7, 423-434.

Samsul, Muhammad. (2006). Pasar Modal dan Manajemen Portofolio. Jakarta:Erlangga.

Sehgal, Sanjay dan Vibhuti Vasishth. (2015). Past Price Changes, Trading Volume and Prediction of Portfolio Returns. Journal of Advances in Management Research, 12(3), 330 - 356.

Sidqi, Fandi Ichwan dan Bulan Prabawani. (2017). Analisis Harga Saham dan Volume Perdagangan Saham Sebelum dan Sesudah Melakukan Stock Split. Jurnal Ilmu Administrasi dan Politik, 6(1), 44-54.

Situmeang, Santa. (2015). Analisis Pengaruh Volatilitas Harga, Likuiditas Saham, EPS, Sie Firm, Momentum Overnight terhadap Return Saham. Semarang: Universitas Diponegoro.

Song, Frederick (Fengming), Hui Tan, dan Yunfeng Wu. (2005).Trade Size, Trade Frequency, and The Volatility-Volume Relation.The Journal of Risk Finance, 6(5), 424-437.

Sugiyono. (2013). Metode Penelitian Manajemen. Bandung: CV. Alfabeta.

Sugiyono. (2015). Metode Penelitian Pendidikan (Pendekatan Kuantitatif, Kualitatif, dan R\&D). Bandung: CV. Alfabeta.

Sugiyono. (2016). Metode Penelitian Kuantitatif, Kualitatif dan R\&D. Cetakan ke 23. Bandung: CV. Alfabeta

Surya, Kuntara. (2016). Pengaruh Harga Saham, Volume Perdagangan, Market Value, dan Varian Return terhadap Bid Ask Spread (Studi Empiris pada Perusahaan yang Terdaftar di Daftar Efek Syariah). E-Journal Akuntansi Fakultas Ekonomi, Universitas Muhammadiyah Yogyakarta.

Sutrisno, Bambang. (2017). Hubungan Volatilitas dan Volume Perdagangan di Bursa Efek Indonesia. Jurnal Bisnis dan Manajemen, 7(1), hal. 15 - 26.

Suwanda, Hary. (2011). Tetap Untung Ketika Saham Turun. Jakarta: PT. Gramedia Pustaka Utama. 
Ni Putu Ayu Supriati, Pengaruh Volume Perdagangan...

Tandelilin, Eduardus. (2017). Pasar Modal Manajemen Potofolio dan Investasi. Yogyakarta: PT Kanisius.

Tim Studi Volatilitas Pasar Modal Indonesia dan Perekonomian Dunia. (2011). Volatilitas Pasar Modal Indonesia dan Perekonomian Dunia. Jakarta: Kementerian Keuangan Republik Indonesia, BAPEPAM-LK.

Utama, Made Suyana. (2016). Aplikasi Analisis Kuantitatif untuk Ekonomi dan Bisnis. Denpasar: CV. Sastra Utama.

Wahyuliantini, Ni Made. (2015). Pengaruh Harga Saham, Volume Perdagangan Saham, dan Volatilitas Return Saham pada Bid-Ask Spread. Jurnal Manajemen, Strategi Bisnis dan Kewirausahaan, 9(2), hal. 146-155.

Bursa Efek Indonesia. Data Harga dan Volume Perdagangan Saham 2013-2018. www.idx.co.id. (diakses pada September 2018)

Yahoo Finance Team. Data Harga dan Volume Perdagangan Saham 2013-2018 di di BEI dan NYSE. www.finance.yahoo.com. (diakses pada September 2018) 